\title{
The Representation of Women in Street Songs: A Critical Discourse Analysis of Egyptian Mahraganat
}

\author{
Mai Samir El-Falaky \\ College of Language and Communication, Arab Academy for Science and Technology \& Maritime Transport, Cairo, Egypt \\ E-mail: maismf@hotmail.com
}

\author{
Doi:10.7575/aiac.alls.v.6n.5p.1 \\ URL: http://dx.doi.org/10.7575/aiac.alls.v.6n.5p.1
}

Received: $15 / 04 / 2015$

Accepted: 04/07/2015

\begin{abstract}
The study investigates the representation of male and female gender identities in Egyptian street songs called Mahraganat. The study discusses the issue with reference to two common songs spreading among young commoners. Since the songs are written by writers who descend from low-standard social group, the analysis exhibits both cultural and societal notions related to how males and females are portrayed in such kind of music. This study attempts to describe how males describe their social group in comparison to the social group to which the women belong. It, thus, constructs the social identity of males and females through the lyrics of this new genre of music. The findings from such an analysis answer the question about such genre within its social context and the ideologies by which it is dominated reflecting the discursive construction representation of gender and sexual identity.
\end{abstract}

Keywords: gender, identity construction, genre, ideologies

\section{Introduction}

A rapidly growing genre, Mahraganat which is translated as 'festivals', is a form of public folklore that has appeared and spread recently among commoners in a very rapid pace. Imitating the 'hip-hop' music style, mahraganat discusses controversial topics in the Egyptian societies, especially those who belong to the working-class. One of the mostly covered topics is sex and male-females relationships. Being 'shaabi music', or the music of the poor, these songs touch the pains of the people who descend from such socioeconomic background. The inability to get married and get involved in an appropriate relationship entails the rise of such kind of songs that represent an outburst of their frustrated expectations of a better life and are, thus, seen by them as a critical cry for the surrounding circumstances. Through the wide production of these songs with minimal production costs and despite the low sound quality and the vulgar style, these songs still find their way among the Egyptian society. Thus, this type of discourse is, interestingly, chosen for the analysis in this paper so as to reveal some of its aspects and its prospective implications.

\section{Research Objectives}

The study at hand seeks to provide a better understanding of how the discourse of songs plays a role in constructing gender identities. The paper, also, aims at highlighting the relationship between discourse and the notion of gender in two Mahraganat songs. Thus, the question this research article will try to answer can be structured as follows:

- How does discourse play its role in the representation of women in a rapidly growing genre of Mahraganat and its lyrics?

\section{Review of Literature}

The definition of Discourse cannot be related to just texts written without an intention of its writer. Rather, as defined by van Dijk (1997a), it is perceived as a practical, social and cultural phenomenon. van Dijk describes the discursive language as composed of more than a series of words or clauses and sentences. It is a "...sequence of mutually related acts" (p.3), where language users are not only speakers, writers or listeners, they are also members of social institutions and social categories, professions, organizations, or communities. Being such members they have the ability to construct and display their social roles and identities by the language they use.

Discourse Analysis has naturally emerged as a result of the lack of examination of nationalist ideologies, social movements and the political construction of social identities (Howarth and Stavrakakis, 2000). It is the need to study gender and identities in addition to the socioeconomic contexts that makes the emergence of Discourse analysis an urgent necessity. Howarth and Stavrakakis (2000) claim that "issues of identity formation, the production of novel ideologies, the logics of social movements and the structuring of societies by a plurality of social imaginaries are central objects of investigation for discourse theory" (p.1-2).

van Dijk (1997a) manifests the importance of discourse analysis as being studied "not only as a form, meaning and mental process, but also as complex structures of interaction and social practice and their functions in context, society and culture" (p.7). This kind of interaction, as proposed by van Dijk, is intentional, controlled and purposeful that aim at communicating acts. 
Liu (2008) adds that this form of social practice is tied to specific historical and socio-cultural contexts. He also asserts that discourse is regarded as a means by which existing social relations and identities are produced or contested and challenged. Besides, Fairclough manifests the dual character of Discourse Analysis claiming that

Discourse analysis correspondingly has a doubly relational character: it analyses relations between discourse and other elements of the social, and it analyses relations between linguistic/semiotic elements of social events and linguistic/semiotic facets of social structures and social practices, including 'discourses' (2005, p.916).

Based on van Dijk's approach to discourse analysis, Butler (2003) views some of the principles that discourse study should adopt. He claims that the study of discourse must deal with authentic, naturally occurring data. It must also recognize the dynamic nature of discourse. Participants, as Butler argues, act as members of particular social and cultural groupings and not only elements of the discourse. More importantly, the study of discourse must describe the functional and semantic relationships between its units.

Fairclough (1989) adopts critical discourse analysis (CDA) as an approach for analyzing social interactions in a way which focuses on their linguistic elements. For Fairclough, these linguistic elements are determinants of the social relationships within the social system. As an approach for discourse analysis, CDA links many interdisciplinary approaches for the sake of providing more profound analysis for discursive practices. Fairclough describes CDA as 'critical' as it analyzes and criticizes the connection between properties of texts and social processes as represented in the ideologies and in power relations. His framework approaches the analysis in three dimensions. For him, the discursive practices involve, simultaneously, "(i) a language text, spoken or written, (ii) discourse practice (text production and text interpretation), (iii) sociocultural practice." (1995, p. 97). The following diagram captures Fairclough's representation of this approach.

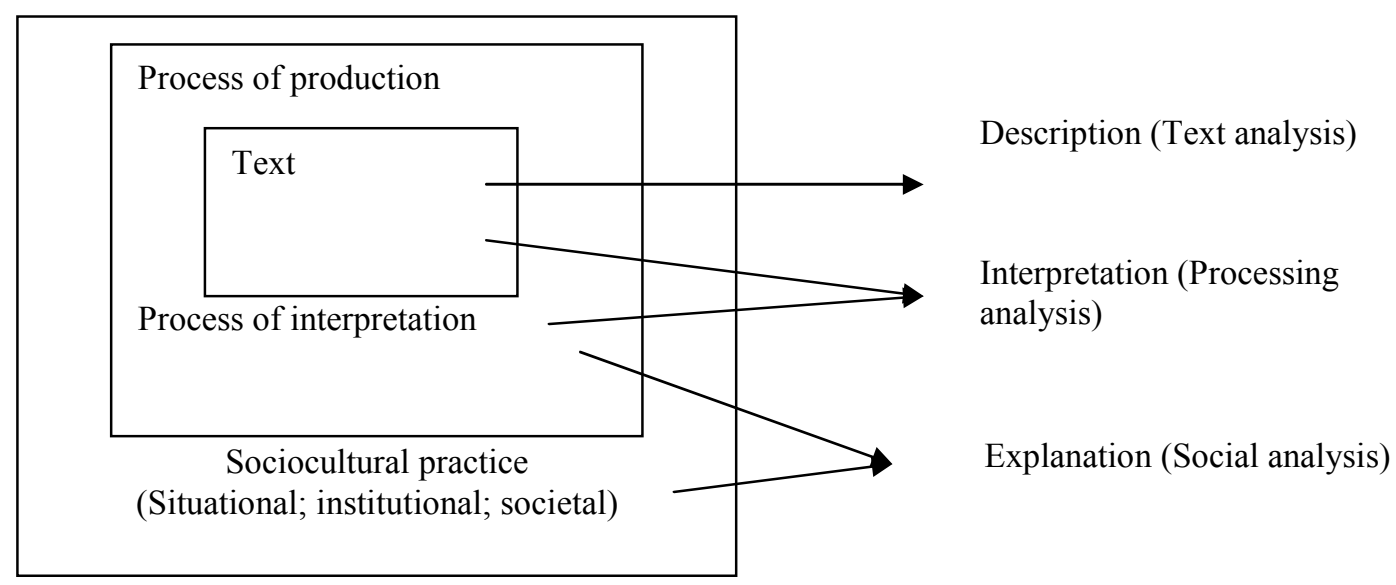

Figure 1. Dimensions of Discourse Analysis (Fairclough, 1995, p.97)

According to Fairclough (1995) this method of discourse analysis includes linguistic description of the language text, interpretation of the relationship between the productive and interpretive discursive processes and the text and, finally, explanation of the relationship between the discursive processes and the social practices.

There are various methodologies for doing CDA reflecting the theoretical and philosophical orientations of the researchers (Mayr, 2008, p. 9). One of these methodologies is Fairclough's. Fairclough (1995) works from a Marxist perspective about neo-capitalism arguing that the task of CDA is to identify relations of domination and inequalities and how they are produced and reproduced in discourse. van Dijk (1997a), on the other hand, defines his socio-cognitive framework focusing on the relationship between social systems and social cognition. The discourse-historical approach adopted by Wodak (2002) traces the history of phrases and arguments focusing on political issues such as racial discrimination.

\subsection{Discourse as a Social Practice}

The work of Chouliaraki and Fairclough (2001) describes the notion 'practices' as "habitualized ways, tied to particular times and places, in which people apply rescourses... to act together in the world" (p. 21). That is, practices are processes performed by people who are living their lives in the society. These practices, as claimed by Chouliaraki and Fairclough, take place throughout the social life in every aspect of life such as politics, economy or any other domain.

Fairclough and Wodak (1997) describe CDA as analyzing real social interactions which take a linguistic form. It views the deep relationship between language and society. In other words, "It is a form of intervention in social practice and social relationships". (Fairclough and Wodak, 1997, p. 258). This, in turn, as van Dijk (1997a) claims, attracts the attention to its interdisciplinary nature, as combining diverse perspectives in its own analysis, hence enabling to address a vast number of social problems. 
Kress (1996) goes farther than this describing CDA as having a 'political project' of the "inequitable distribution of economic, culture and political goods in contemporary societies" (p.15). That is, critical language studies texts and social practices implied by those texts uncovering inequalities with all its forms. Supporting this, van Leeuwen (2009) verifies that CDA plays an important role in maintaining and legitimizing inequality, injustice and oppression in society by using appropriate discursive methods. Summing it all up, Meyer and Wodak (2000) state that CDA is specifically interested in institutional, political, gender and media discourse in which explicit forms of struggle and conflict are embedded.

van Dijk (2002) limits the domain of CDA to what he calls 'theoretical triangle'. His triangle describes three levels of analysis, namely, discourse, cognition, and society. For him, discourse covers all the communicative events whether written or spoken. Secondly, cognition, involves personal as well as social cognition, beliefs and goals and any other mental representation involved in discourse. Finally, society in the theoretical triangular includes the local microstructures, societal and political structures, groups, institutions, systems, social relations and processes.

\subsubsection{Gender, Discourse and Power}

The concept of 'Power' is defined as a form of social activity exercised by a certain person to get someone to do something. Watt (1991) exemplifies this definition as follows:

$\boldsymbol{A}$ exercises power over $\boldsymbol{B}$ when $\boldsymbol{A}$ affects $\boldsymbol{B}$ in a manner contrary to $\boldsymbol{B}$ 's initially perceived interests, regardless of whether $\boldsymbol{B}$ later comes to accept the desirability of $\boldsymbol{A}$ 's actions. (p. 62)

It is largely agreed upon that language gains its power through its deployment within the agendas of powerful people. And the notion 'powerful' here is associated with rank and status, as hierarchies are built around the relative positions of social, professional and political power (Wang, 2006). For Wang, "...power can be characterized as the ability to control and constrain others; as the capacity to achieve one's aim; as the freedom to achieve one's goals and as the competence to impose one's will on others" (p.531).

Mayr (2008) names three strands of research that have been identified in the study of the relationship between discourse in a certain institution and power:

(1) the study of how members of oppressed groups can 'discursively penetrate the institutionalized form of their oppression'; (2) how subordinate individuals 'discursively frame their own subordination' thereby perpetuating it; and (3) analysis of how dominant groups 'discursively construct and reproduce their own positions of dominance'. (p. 3)

Wodak and Clarke (2009) argue that this power is exercised through three related modes, i) the power in discourse; ii) power over discourse; and iii) the power of discourses. They claim that the first mode refers to the struggle of different actors over different interpretations of meaning through practices related to the selection of specific linguistic codes and rules for access to meaning-making forums (i.e. meetings) and interaction (i.e. turn-taking, decision-making, etc.). The second mode, according to them, refers to means through which various groups of actors are denied or granted 'access to the stage' through processes of inclusion and exclusion. The third and final mode is interconnected with ideological production and their interpretations (Wodak and Clarke, 2009, p.278).

\subsection{Gender and discourse}

Hellinger et.al, like other scholars (Nuyts,1990; Lakoff, 2004; Eckert and McConnell-Ginet, 2013), assure the importance of understanding how gender is represented in a language. “... since an individual's sense of self includes an awareness of being female or male, it is important to develop an understanding of the ways in which gender is negotiated in a language" (p.3). It is the scope of critical discourse analysis that is mainly concerned with the use of language in the process of inequality and oppression between social members. Gender difference is not an exception. The role of males and females is known to be constructed the moment they were born and is, then, framed according to the discursive and social practices throughout time. Wodak (1997) stresses the point that the socialization process plays a fundamental role of how men and women see themselves. They are labeled during their childhood. Such attributions, according to Wodak, are directly connected to the societal evaluation of the female and her status in the society. However such definitions of gender and its attributes may change from one generation to another. Wodak says "In the context of this perspective, it is more coherent to talk of gender as the understanding of how what it means to be a woman or to be a man changes from one generation to the next and how this perception varies between different social classes"(p.4).

Most of the studies carried out reveal that gender studies are inseparable from discourse analysis. Rather, gender studies are deeply integrated into discourse analyses. Meyer and Wodak (2000) state that CDA capitalizes most of it research on gender as well as media discourse in which explicit forms of struggle and conflict are embedded. Also, Talbot (2010) stresses the importance of the study of discourse that focuses on gender identities. According to Talbot, such discursive examination reveals "the way language contributes to social reproduction and social change." (p.117). Critical discourse analysis is, thus, mainly concerned with how language is used in a non-obvious way in depicting self and other's image, thus defining social relations between males and females assign in who is supposed to be powerful and who is regarded to be oppressed. 
Talbot says "a single individual is placed in a wide range of positions as a social subject. These are known as subject positions. They are set in discourse. A person does not exist independently of them; she [a woman] is constituted as a person in the act of working with various discourses" (p.124). That is, gender roles are acted in the society according to the context of situation which is already depicted in the frame of the context of its culture.

Stereotypically portrayed “... in the construction of gendered identities, femininity and masculinity operate as two poles of a gender dichotomy where the masculine (man) is positioned as active and the feminine (woman) as passive"(p.93).

\section{Research Method}

Critical Discourse Analysis has been utilized in this research to analyse the songs. The methodology adopted is a qualitative data analysis of the two songs aiming at establishing a link between discourse as a social practice and construction of gender identities. The data is selected on the basis of the most heard songs among commoners. The two songs are well-known among young people who claim that these songs, among others, reflect the real life they are living.

\section{Data Analysis}

\subsection{Theme and Analysis of the First song}

The first song is Mesh hateegy.. mesh haruh which is translated as 'Are you coming.. No I am not'. The song includes description of females who are trying to live a life which is completely different from the life they were initially originated in.

The song opens with a young female making a phone call to someone she loves inviting him to her house. She calls him

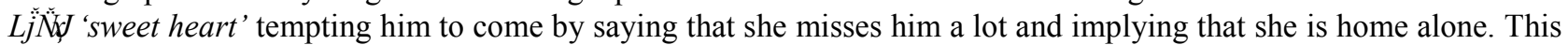
kind of flirting deviates from the Egyptian culture where strange males and females are prohibited to be alone in one room.

The man replies to such invitation with a decisive tone that he is not going. He is stressing his refusal VDIẼL $\$ N$ E $35 \eta$

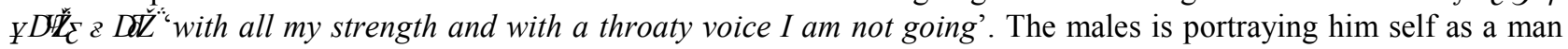
who is striving to reject this very tempting call. Such decisive tone is also reflected in the use of the personal pronouns 'my' and 'I'. Psychologically, as argued by Hellinger et.al. (2015), "an appropriate use of personal nouns may contribute towards the maintenance of an individual's identity" (p.3). The man describes himself as a man of honor. He, as implied in the song is a man of actions who is not going to do the wrong which is supported by the 'bald' flirting woman.

Then, the song goes in to a detailed description of females who persist to break all the societal norms and the cultural regulations even when they themselves know that this should not be done. The male is refusing such type of females complaining that العقل من جو ايا طاير و الدم يغلي ياناس فاير any mind is mad and blood is boiling from anger'. The first image of the female is portrayed as a girl going to a party till it is very late at night. Her mother unexpectedly came to her. The female is screaming that her mother is going to show her very hard times. The mother, who descends also from a low standard community shouts at her daughter asking her about the identity of that man she is dating. The girl replies that he is her colleagues and is going to propose. This takes us to the fact that the female's reply about marriage proposal represents an excuse to the mother. She is going to get married and this is, according to the Egyptian culture, the only excuse for being with a strange man alone in a closed area. The mother blames her daughter about such kind of love. She advices her daughter that this will make her worthless in his eyes. The narrator of the song comments again by saying that this is how modern-looking girls are breaking the norms of the Egyptian culture. According to the narrator modern females are doing great efforts to seduce the males who stand 'helpless' before their invitations and calls. According to Hellinger et.al. (2015), the inappropriate use of identity markers or derogatory language may cause irritation or anger of feeling of inferiority. It is clear in the detailed description of the practices of the woman that the man is looking down at her while raising himself in a higher rank of respect and self esteem.

The song takes us again to a conversation between the mother and the girl expressing the struggle between the old traditions and the newly intervening conceptions. The modern-like girl uses borrowed words to show how prestigious she is or at least should be.

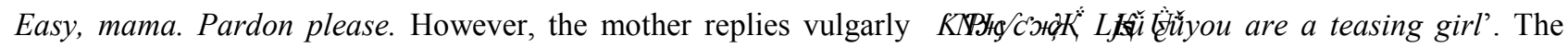
mother is describing her girl as a crazy uncomfortable girl. The girl's original vernacular tone appears here. She replies with that vulgar tone reflecting her original social standard Li் context, it is important to notice how another character is involved in the story. It is the mother, who is also a female. The narrator of the story makes use of the feminine lexical derogatory references that stress his intention that the moral misbehavior embraces all women regardless their social roles.

The narrator appears again by claiming a rejection to such type of girls who attempt to seduce the helpless men with all their tools, either by their catching eyes or by playing hard to get their target. The narrator again portraits a mocking image of the low-standard girls who try to have a fake appearance. He gives an example of a girl who descends from a low standard living in a slum, but she goes to a club 'wearing good-looking shoes with a ribbon', 'use the social networks with a fake status', 'draws a tattoo', 'uses the English language in her Arabic talks' and finally 'wears a lot of makeup'. The narrator ends the song with a negligence tone that he does not care if the girl leaves him as he had the intention to leave her in the first place but does not have the guts to take the decision because he keeps her sake. The man is not going to accept her offer and he is not going to the party. 
The above description of the song reflects the construction of gender discursively through the linguistic choices supported by both the first and third person narration technique. The identity of the males is represented as a man holding on strongly to his manhood and fighting, with all his power, the unaccepted norms produced by modern-like females. Males are depicted as ideologically powerful characters dedicating themselves to keeping the morals in the society. Females on the other hand, are shown as sexual subjects who spread the immoral attitudes in the community. All their goals is to rebel against the morals and the well established norms and traditions. Females are depicted as sexual objects who seek to seduce the males which make them seem worthless. Females are portrayed as making use of their bodies to call the men. The identity of men is said to be fighting for their ideological beliefs that women are not created for any thing except being ruled by men. Men are said to have the power to reject all the immoral calls by coquettes. Males are seen as role models who may appear weak before the women of sexual power.

The song employs the narrator's technique in order to give a bird eye view about the struggle between the old traditions, the mother, and the modernity intervention symbolized by the girl who is behaving immorally in a society which is supposed to be culturally conservative. The song may represent a discursive structure that portrays the role of the modern women in society. The song describes the woman's sexual role which is downgraded by males if they do not follow the ideologically preconceived norms.

The discourse of the song reflects the institutionalized structure of social fabric. The societal components such as economy are reflected through the image of low standard females who try to deroot themselves from the conceived ideological backgrounds which are deeply rooted in the Egyptian society. This takes place by situating her self in physical contexts which is different from her place of originations such as 'club', 'party'. It could also be reflected through different cultural behaviors such as 'speaking different language' or 'drawing tattoo'. According to the song, males are the only members who follow and keep the institutionalized norms in the society. The discourse of the song implies that men are emotionally strong, moral keeping through marinating the norms of the society which are distorted by corrupt females. They see themselves as having the power to direct the female's ill-behaviors.

This song is a good example of gender stereotyping in which, in the age of modernity, men are positively depicted and women are shown to have different unacceptable behavior in the light of the moral ideological background rooted in the Egyptian society.

\subsection{Theme and Analysis of the Second Song}

The second song is Ana kol mamshy atkaabel fel bet ely btestahbel which is translated as 'Every time I crumble with the girl who is playing a fool'. The song describes a girl who attempts to build a relationship with an unknown guy behind her father's back.

The narrating voice of this song is a first person male character who is telling his personal story with an unknown girl who is pursuing him. The male narrator begins the song by stating that every time he crumbles with this girl who, as he calls, is fooling others. The girl keeps chasing him to the extent that she keeps awake till late at night sending him her pictures. The first person pronouns انا 'me' personifies the story attempting to describe how disgusted he is from that girl who keeps asking him to develop a relationship through meeting and spending time with him. The man attempts to

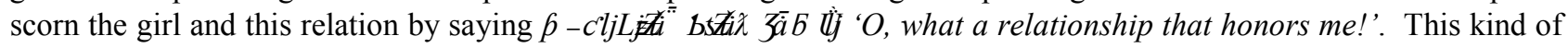
commentaries, as argued by Lakoff (2004), is a source of discomfort for the female recipients. Such derogatory terms are intended to describe the women morally, sexually and physically, especially when such descriptions go from specification to generalization. The male narrator goes on to describe all the female characters whether 'سمرة'dark' and the بيضا'white'. Generalization is, also, extended to all the male characters who, also, feel sick because of the behaviors of such girls. This is clear in the first person plural pronoun suffix ' $\square-{ }^{-} u$ ' ' referring to the males in the word $\square \square$ 'they stifle us' where the third person plural pronoun !- 'they' refers to the females. According to the narrators all female types have the same attributes and have same effect on the males' feeling. That is, every time males see such women, males are disgusted and feel sick. The girls keep seducing them with their camera and their revealing clothes that strike them. In this context, the narrator is downgrading the woman's image by how he describes all her actions. In this regard, Lakoff (2004) claims “... a woman's reputation and position in society depend almost wholly on the impression she makes upon others, how others view her". (p,120) Victimizing himself he shows himself as a good mannered person who better keeps silent not wanting to abuse them any more هنكت احسن ما افسر 'I will keep silent and won't explain more'. The narrator returns again to that particular girl who keeps following him. She tells her mother about her relations but when it comes to her father he gets angry but she could make it behind his back. In this part, the narrator defends the whole male characters and throwing the blame on the females. That is the mother accepts her daughter's sick behaviors while the father denies and rejects such morals. The song ends with a dirty flirting from the narrator to such kind of girls resembling her to the butter and cream in shape and in taste.

The song attempts to represent the stereotyping the women as being oddly liberated by breaking all the cultural norms. The narrator of the story depicts the female character in a way different from the conventional traditions well know in the Egyptian society. This proves what Eckert and McConnell-Ginet (2013) asserts, "The development of such nontraditional practices in recent years has contributed to changing the meaning of male and female and thus to changing the gender order, the social structures that in their turn shape gender practices" (p.36). The preconceived ideology of the woman as a domestic figure who does not seek to get in direct contact with males through her physical appearance has shamefully been challenged. This preconceived image of women has been distorted and new identity categories and labels have been constructed (Eckert and McConnell-Ginet, 2013). 
The features attributed to the girl in particular or all the women in general constructed the image that women represent a social group different from that of males'. In this song, males see those women as out-group and see themselves as ingroups who share the same problem of immorality. According to the song, women do nothing except showing her beauty. Women see themselves as sexual objects that have one target, that is, to attract men. The linguistic choices made in this song create and reflect the unequal acquisition of moral beliefs and that men are again helpless and in need of power to reject such irresistible seductive practices performed by females.

\subsection{Mahraganat and its Contextual Analysis}

The analysis of the two songs in this study reflects what Fairclough (1995) called a three-level scheme of analysis. The analysis proves that the socio-economic factors at the macro-level has a deep impact on the interpretation of the ideological transmission of the internal meanings embedded in the lyrics of the song, and this is demonstrated via the micro-level of discursive practice and the selection of linguistic features of the songs.

The analysis of the linguistics choices sheds light on the discursive construction of woman's image as depicted by males. The analysis also shows the internal mental models of the female character as a sexual object whose main target is to seduce men who, in turn, are trying to resist such immoral calls. Males are portrayed as those who have the power of morality and good deeds. Women are the source of immorality and are, thus, running the worldly pleasures. The identity representation that can be inferred from such type of songs constructs women as needy, sexual objects, body oriented and descendent from low socio-economic contexts. Such representation of women gives advantage of men over women creating a negative image that disadvantages women who are attributed with sexual identity markers.

\section{Conclusion}

This study has attempted to reveal how the manifestation of gender roles takes place within the context of the Egyptian society. The Egyptian society has a context of culture which seems to be different from the other Arab countries. Recently, the criteria of measuring what is moral and what is not has become blurred. The song highlights how male signers who are typically the singers of such Maharaganat portray themselves as the good We while the females are described as the bad They.

Both songs are full of sexual insinuations which are spread among the youth especially the males due to the type of this genre which attracts males rather than females. It can not be denied that the spread of such kind of songs falsely generalize negative and unaccepted cultural values. The female body and her seducing manners are they only focus of attention. The songs stereotype women as a seducing object rebelling against their culture and norms which, as a result make her incapable of performing any constructing role in the society.

These songs represent an over dose of description of Arab woman who seek to distort the Arab culture in contrast to the efforts paid by men who see themselves as guardians of the religious or social cultural aspects.

The songs are selected for the purpose of identifying the element of social construction of gender. By employing Critical Discourse Analysis, the analysis has attempted to highlight the social practices as well as the ideological back grounds revealed in the age of modernity. In general, it can not be denied that there is a collapse of societal textures where the traditional norms of society are distorted. But, who is responsible for such result is a question still remains unanswered. The analysis of gender identities through different types of discourse may help us reach a comprehensive conclusion. Critical Discourse Analysis is, thus, seen as a tool by which members of the society convey how the see the Self and the Other.

\section{References}

Allan, E. (2012). Policy Discourses, Gender, and Education: Constructing Women's Status. UK: Routledge Publications.

Brown, G. \& Yule, G. (1988). Discourse Analysis. Cambridge: Cambridge University Press.

Butler, C. (2003). Structure and Function: A Guide to Three Major Structural- Functional Theories. USA: John Benjamin's Publishing.

Caldas-Coulthard, C. and Iedema, R. (2008). Identity Trouble:Critical Discourse and Contested Identities: UK: Macmillan.

Chouliaraki, L. and Fairclough, N. (2001). Discourse in Late Modernity. Edinburgh: Edinburgh University Press.

Dunmire, P. (2005). Preempting the Future: Rhetoric and Ideology of the Future in Political Discourse, Discourse Society, 16 (4), 481-513.

Duszak, A. (2009). Discourses "of course"? In Jan Renkema (Ed.). Discourse, of Course: An Overview of Research in Discourse Studies. (pp.37-51). USA: John Benjamins Publishing.

Eckert, P. and McConnell-Ginet, S. (2013). Language and Gender. USA: Cambridge University Press.

Fairclough, N. (1989). Language and Power. USA: Longman.

. (1995). Critical Discourse Analysis: The Critical Study of Language. USA: Longman. 
. (1996). Technologisation of Discourse. In Carmen Rosa and Malcolm Coulthard (Eds.), Texts and Practices. (pp. 71-83). London: Roultedge.

. (2003). Analysing Discourse: Textual Analysis for Social Research. London: Routledge.

(2005). Peripheral Vision: Discourse Analysis in Organization Studies: The Case for Critical Realism. Organization Studies, 26 (1), 915-939.

Fairclough , N., \& Wodak, R. (1997). Critical Discourse Analysis. In Teun van Dijk. (Ed.), Discourse Studies: A Multidisciplinary Introduction. Volume 2. (pp. 258-283). London: Sage Publication.

Fowler, R and Kress, G. (1979). Critical Linguistics. In R. Fowler, B.Hodge, et al (Eds.). Language and Control. (pp.185-213). London: Routledge and Kegan Paul.

Hawkes, D. (1996). Ideology. London: Roultedge.

Hellinger, M. et.al. (2015). Gender across Languages: the Linguistic Representation of Women and Men. In Marlis Hellinger and Heiko Motschenbacher. (Eds.), Gender Across Languages. (pp. 1-26). USA: Johan Benjamin.

Howarth, D \& Stavrakakis, Y. (2000). Introducing Discourse Theory and Political Analysis. In David Howarth and Yannis Stavrakakis et al. (Eds.), Discourse Theory and Political Analysis: Identities, Hegemonies and Social Change. (pp. 1-23). USA: Manchester University Press.

Hyatt, D. (2005). Time for a Change: a Critical Discoursal Analysis of Synchronic Context with Diachronic Relevance. Discourse \& Society, 16 (4), 515-534.

Johnstone, B. (2008). Discourse Analysis. USA: Blackwell Publishing.

Kinsley, P. (2014, May 9). Cairo's Street Music Mahraganat both Divides and Unites. The Guardian. Retrieved from http://www.theguardian.com/world/2014/may/09/egypt-cairo-street-music-mahraganat-grime

Lakoff, R. (2004). Language and Woman's Place: Text and Commentaries. USA: Oxford University Press.

Liu, Y. (2008). The Construction of Patriotic discourse in Chinese Basal Readers. In Rosana Dolón and Júlia Todolí (Eds.), Analysing Identities in Discourse (57-82). USA: John Benjamins Publishing.

Martin, J. R. and Rose, David. (2005). Working with Discourse. London: Continuum Publishing Company.

Mayr, A. (2008). Introduction: Power, discourse and institutions. In Andrea Mayr (Ed.). Language and Power:An Introduction to Institutional Discourse. (pp. 1-25). London: Continuum.

Meyer, M. (2002) Between Theory, Method, and Politics: Positioning of the Approaches to CDA. In Ruth Wodak (Ed.) Methods of Critical Discourse Analysis. (pp. 14-30). London: Sage Publications.

Meyer, M \& Wodak, R. (2000). Methods of Text and Discourse Analysis: London: Sage Publications.

Mills, S. (2004). Discourse. London: Routledge.

Moore, J. D., \& Wiemer-Hastings, P. (2003). 12 Discourse in Computational Linguistics and Artificial Intelligence. In M. A., \& Goldman, S. R. (Eds.) Handbook of Discourse Processes, Graesser, A. C., Gernsbacher, (pp. 439-478). Mahwah, NJ: Lawrence Erlbaum Associates.

Nuyts, J. (1990). The Linguistic Representation and Conceptual Knowledge Representation. In Jan Nuyts et.al (Eds.) Layers and Levels of Representation in Language Theory: A Functional View. (pp. 295-312). USA: Johan Benjamin.

Renkema, J., (Ed). (2009). Discourse, of Course: An Overview of Research in Discourse Studies. USA: John Benjamins Publishing.

Talbot, M. (2007). Media Discourse: Represnetation and Interaction. Edinburgh: Edinburgh University Press. . (2010). Language and Gender. USA: Polity Press.

Thompson, John B. (1984). Studies in the Theory of Ideology. Los Angeles: University of California Press.

van Dijk, T. (1996). Discourse, Power and Access. In Carmen Rosa and Malcolm Coulthard (Eds.), Texts and Practices. (pp. 84-103). London: Roultedge.

(1997a). The Study of Discourse. In Teun van Dijk. (Ed.), Discourse Studies: A Multidisciplinary Introduction. Volume 1. (pp. 1-34). London: Sage Publication.

. (1997b) Discourse as Interaction in Society. In (Teun A. van Dijk Ed.), Discourse as Social Interation. Discourse Studies: A Multidisciplinary Introduction. Volume 2. London: Sage Publications.

. (1998). Ideology: A Multidisciplinary Approach. London: Sage Publications.

(2002) Multidisciplinary CDA: a Plea for Diversity. In Ruth Wodak (Ed.) Methods of Critical Discourse Analysis. (pp. 95-119). London: Sage Publications.

. (2006a). Politics, Ideology, and Discourse. In K. Brown (Ed.) Encyclopedia of Language and Linguistics. (pp. 725-740). Amsterdam: Elsevier publishing.

. (2006b).Discourse, Context and Cognition. Discourse Society, 8(1), 159-177.

. (n.d.) Ideological Discourse Analysis [PDF document]. Retrieved from Lecture Notes Online Web

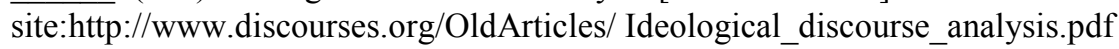


van Leeuwen, T. (1996). The Representation of Social Actor. In Carmen Rosa Coulthard and Malcolm Coulthard (Eds.), Texts and Practices. (pp. 32-70). London: Roultedge.

. (2008). Discourse and Practice: New Tools for Critical Discourse Analysis. Oxford: Oxford University Press.

(2009) Critical Discourse Analysis. In Jan Renkema (Ed.). Discourse, of Course: An Overview of Research in Discourse Studies. (pp. 277-292). USA: John Benjamins Publishing.

Wang, J. (2006). Questions and the exercise of power, Discourse \& Society, 17 (4), 529-548.

. (2010). A Critical Discourse Analysis of Barack Obama's Speeches. Journal of Language Teaching and Research, 1(3), 254-261. DOI:10.4304/jltr.1.3.254-261.

Wodak, R. (1997). Introduction: Some Important Issues in the research of Gender and Disocurse. In Ruth Wodak (ED.) Gender and Discourse. (pp.4-20).UK: sage publications.

(2002). What CDA is about: A Summary of its History,Important Concepts and its Developments. In Ruth Wodak and Michael Meyer (Eds.) Methods of Critical Discourse Analysis. (pp. 1-12). London: Sage Publications.

Wodak, Rh. and Ludwig, C. (1999a). Introduction. In Ruth Wodak and Christoph Ludwig (Eds.) Callenges in a Changing World: Issues in Critical Discourse Analysis. (pp. 11-20). Amsterdam: Die Deutsche Bibliothek.

(Eds). (1999b). Callenges in a Changing World: Issues in Critical Discourse Analysis. Amsterdam: Die Deutsche Bibliothek.

Wodak, R and Meyer, M (eds). (2002). Methods of Critical Discourse Analysis. London: Sage Publications.

Wodak, R. \& Clarke, I. (2009). Organizational Decision-making, Discourse, and Power: Integrating Across Contexts and Scales. Discourse \& Communication, 3 (3), 273-302. 